\title{
The global tropospheric ammonia distribution as seen in the 13-year AIRS measurement record
}

\author{
Juying X. Warner ${ }^{1}$, Zigang Wei ${ }^{1}$, L. Larrabee Strow ${ }^{2}$, Russell R. Dickerson ${ }^{1}$, and John B. Nowak ${ }^{3}$ \\ ${ }^{1}$ Department of Atmospheric and Oceanic Science, University of Maryland College Park, College Park, MD 20742, USA \\ ${ }^{2}$ Department of Physics and Joint Center for Environmental Technology, University of Maryland Baltimore County, \\ Baltimore, MD 21250, USA \\ ${ }^{3}$ Aerodyne Research, Inc., Billerica, MA 01821, USA \\ Correspondence to: Juying X. Warner (juying@ atmos.umd.edu)
}

Received: 13 October 2015 - Published in Atmos. Chem. Phys. Discuss.: 21 December 2015

Revised: 8 April 2016 - Accepted: 10 April 2016 - Published: 2 May 2016

\begin{abstract}
Ammonia $\left(\mathrm{NH}_{3}\right)$ plays an increasingly important role in the global biogeochemical cycle of reactive nitrogen as well as in aerosol formation and climate. We present extensive and nearly continuous global ammonia measurements made by the Atmospheric Infrared Sounder (AIRS) from the Aqua satellite to identify and quantify major persistent and episodic sources as well as to characterize seasonality. We examine the 13-year period from September 2002 through August 2015 with a retrieval algorithm using an optimal estimation technique with a set of three, spatially and temporally uniform a priori profiles. Vertical profiles show good agreement $(\sim 5-15 \%)$ between AIRS $\mathrm{NH}_{3}$ and the in situ profiles from the winter 2013 DISCOVER-AQ (DISCOVER-Air Quality) field campaign in central California, despite the likely biases due to spatial resolution differences between the two instruments. The AIRS instrument captures the strongest consistent $\mathrm{NH}_{3}$ concentrations due to emissions from the anthropogenic (agricultural) source regions, such as South Asia (India/Pakistan), China, the United States (US), parts of Europe, Southeast (SE) Asia (Thailand/Myanmar/Laos), the central portion of South America, as well as Western and Northern Africa. These correspond primarily to irrigated croplands, as well as regions with heavy precipitation, with extensive animal feeding operations and fertilizer applications where a summer maximum and a secondary spring maximum are reliably observable. In the Southern Hemisphere (SH) regular agricultural fires contribute to a spring maximum. Regions of strong episodic emissions include Russia and Alaska as well as parts of South
\end{abstract}

America, Africa, and Indonesia. Biomass burning, especially wildfires, dominate these episodic $\mathrm{NH}_{3}$ high concentrations.

\section{Introduction}

Global ammonia $\left(\mathrm{NH}_{3}\right)$ emissions are increasing due to the increased agricultural livestock numbers coupled with the increasing use of nitrogen fertilization. Atmospheric ammonia has impacts upon local scales, acidification and eutrophication of the ecosystems, and international (transboundary), as well as local, scales through formation of fine ammonium containing aerosols (Sutton et al., 2007, 2008; Galloway et al., 2008; Erisman et al., 2013). Ammonia reacts rapidly with sulfuric $\left(\mathrm{H}_{2} \mathrm{SO}_{4}\right)$, nitric $\left(\mathrm{HNO}_{3}\right)$, and hydrochloric $(\mathrm{HCl})$ acids to form a large fraction of secondary aerosols, i.e., fine particulate matter $\left(\mathrm{PM}_{2.5}\right)$ (particles less than 2.5 micrometers in diameter) (Malm et al., 2004). These ammonium containing aerosols affect Earth's radiative balance, both directly by scattering incoming radiation and indirectly by acting as cloud condensation nuclei (e.g., Adams et al., 2001; Martin et al., 2004; Abbatt et al., 2006; Wang et al., 2008; Henze et al., 2012). A large percentage of $\mathrm{PM}_{2.5}$ can penetrate human respiratory systems and deposit in the lungs and alveolar regions, thus endangering public health (e.g., Pope et al., 2002). Ammonia deposition modifies the transport lifetimes, and deposition patterns of sulfur dioxide $\left(\mathrm{SO}_{2}\right)$ and nitrogen dioxide $\left(\mathrm{NO}_{x}\right)$ (Wang et al., 2008; Henze et al., 2012). Additionally, ammonia increases the concentrations of the greenhouse gas nitrous oxide $\left(\mathrm{N}_{2} \mathrm{O}\right)(\mathrm{EPA}, 2011)$ and, 
together with $\mathrm{NH}_{4}^{+}$content in soils, $\mathrm{NH}_{3}$ is involved in $\mathrm{CH}_{4}$ production and release (Fowler et al., 2009). $\mathrm{NH}_{3}$ can also contribute to increases in radiative forcing through conversion of organic carbon $(\mathrm{OC})$ into brown carbon $(\mathrm{BrC})(\mathrm{Up}-$ dyke et al., 2012). Therefore, monitoring $\mathrm{NH}_{3}$ global distribution of sources is important to human health, with respect to air and water quality, and climate change.

Atmospheric ammonia concentrations have been modeled from a three-dimensional coupled oxidant-aerosol model (GEOS-Chem) (Bey et al., 2001) to estimate natural and transboundary pollution influences on sulfate-nitrateammonium aerosol concentrations in the United States (US) (Park et al., 2004). We used the simulated $\mathrm{NH}_{3}$ fields from GEOS-Chem as the retrieval a priori for this study. A number of ammonia-related science studies and top-down inventory studies are based on GEOS-Chem and its adjoint (Henze et al., 2007; Heald et al., 2012; Paulot et al., 2013, 2014; Zhu et al., 2013; Paulot and Jacob, 2014). The model's ammonia emissions were based on annual data from the $19901^{\circ} \times 1^{\circ}$ GEIA inventory of Bouwman et al. (1997). Table $1 \mathrm{~b}$ from Park et al. (2004) shows a summary of global and contiguous US ammonia emissions for 2001. The inventory's categories include anthropogenic sources: domesticated animals, fertilizers, human bodies, industry, fossil fuels, and natural sources: oceans, crops, soils, and wild animals. Additional emissions from biomass burning and biofuel used were computed using the global inventories of Duncan et al. (2003) and Yevich and Logan (2003), with an emission factor of $1.3 \mathrm{~g} \mathrm{NH}_{3}$ per kilogram dry mass burned (Andreae and Merlet, 2001). For the emissions from domesticated animals and soils, the GEOS-Chem model used the exponential dependencies on temperature reported by Aneja et al. (2000) and Roelle and Aneja (2002), respectively. Ammonia emissions from crops and fertilizers were assumed to vary seasonally with the number of daylight hours (Adams et al., 1999). Seasonal variations in biomass burning and biofuel emissions in the model were specified based on satellite observations (Duncan et al., 2003) and the heating degree-days approach (Park et al., 2004). The GEOS-Chem model can be used to generate 3-D global monthly mean fields of $\mathrm{NH}_{3}$ concentrations, or higher temporal resolutions (e.g., daily or hourly), for various years.

Satellite remote sensing offers unique opportunities to monitor environmental variables with relatively high temporal and spatial coverages. Ammonia measurements with large, daily global coverage are challenging and lacking, partly due to the relatively short (hours to a day) lifetime of $\mathrm{NH}_{3}$ near the Earth's surface, and partly because its retrievals require high sensitivity that can be only obtained from areas with high thermal contrast (TC, the temperature difference between that of the surface temperature and of the first discernable atmospheric layer) near the surface (Clarisse et al., 2010). First measurements of ammonia from space were reported over Beijing and San Diego, CA areas, as examples, with the Tropospheric Emission Spectrometer (TES, Beer et al., 2008) and in biomass burning plumes with the Infrared Atmospheric Sounding Interferometer (IASI, Coheur et al., 2009) satellite. Shephard et al. (2011) documented the TES ammonia retrieval methodology. TES $\mathrm{NH}_{3}$ data have been utilized jointly with GEOS-Chem in various emission source studies (e.g. Alvarado et al., 2011; Pinder et al., 2011; Walker et al., 2012; Zhu et al., 2013). Luo et al. (2015) compared TES $\mathrm{NH}_{3}$ versus carbon monoxide (CO) ratios, using data from the year 2007, to those of the GEOS-Chem model with a focus on biomass burning emissions using TES representative volume mixing ratio values (Shephard et al., 2011).

The first global map of ammonia was created from IASI measurements by correlating observed brightness temperature differences between strong $\mathrm{NH}_{3}$ absorbing channels and weak ones to $\mathrm{NH}_{3}$ total columns using averaged data sets from 2008 (Clarisse et al., 2009). It was later concluded that this method tends to underestimate the global emission inventories at a number of global $\mathrm{NH}_{3}$ hotspots using IASI radiances. Clarisse et al. (2010) examined the ammonia amounts in the San Joaquin Valley of California in the US using an optimal estimation (OE) retrieval method (Rodgers, 2000 ) with a global uniform a priori and IASI radiances and compared them with TES measurements. They studied the factors influencing the ability to use satellite infrared (IR) instruments to retrieve accurate $\mathrm{NH}_{3}$ columns and concentrations, finding that the main factors were $\mathrm{NH}_{3}$ concentrations and thermal contrast. They concluded that through retrieval and forward radiative transfer model runs, if both of the $\mathrm{NH}_{3}$ concentrations and thermal contrast are large enough, it is possible to quantify ammonia near the lowest level of the atmosphere. R'Honi et al. (2013) discussed the elevated concentrations of $\mathrm{NH}_{3}$ and $\mathrm{HCOOH}$ emitted by the 2010 Russian wildfires. Additional IASI $\mathrm{NH}_{3}$ algorithm approaches and validations are also discussed by Van Damme et al. (2014, 2015) and Whitburn et al. (2015). Heald et al. (2012) used IASI ammonia products jointly with the GEOS-Chem output to study inorganic aerosol loading and atmospheric ammonia concentrations over the US.

Global ammonia sources and variability based on continuous monitoring with longer than a decade record (13 years) have not been hitherto available. This study introduces a newly developed daily and global ammonia product from the Atmospheric Infrared Sounder (AIRS) on the NASA EOS Aqua satellite, spanning September 2002 through August 2015. The AIRS orbit covers nearly the entire globe twice daily, and due to cloud clearing, recovers up to $70 \%$ of cloudy coverage (Susskind et al., 2003; Warner et al., 2013). Additionally, AIRS is in the afternoon Equator crossing time; and therefore, it offers high sensitivity due to higher surface temperature and provides higher thermal contrast to $\mathrm{NH}_{3}$ measurements.

In the next section, we detail the methodology used to develop the global products of $\mathrm{NH}_{3}$ and present the discussions for data quality. In Sect. 3, we show examples of validation cases using in situ data from a recent NASA 
aircraft mission - DISCOVER-AQ (Crawford et al., 2014) (http://discover-aq.larc.nasa.gov). Section 4 illustrates the global distributions of the $\mathrm{NH}_{3}$ sources. We demonstrate the seasonal variability of $\mathrm{NH}_{3}$ concentrations using AIRS 13 year measurements in Sect. 5 , before summarizing results in Sect. 6.

\section{Methodology}

The AIRS instrument is a grating spectrometer with 2378 separate spectral channels between 650 and $2670 \mathrm{~cm}^{-1}$ (15.3-3.8 $\mu \mathrm{m})$ with a spectral resolving power on the order of 1200. Twelve channels of the AIRS radiances in the window regions $\left(860-875,928-932\right.$, and $\left.965-967 \mathrm{~cm}^{-1}\right)$ are currently used to retrieve $\mathrm{NH}_{3}$. These channels are carefully selected so that the retrievals are based on the $\mathrm{NH}_{3}$ sensitivity, while the effects of the surface and overlapping gases are minimized. AIRS cloud clearing, described by Susskind et al. (2003), increases the data coverage significantly to nearly $50-70 \%$ of the total measurements, instead of the pure clear coverage of approximately $10-15 \%$ at a $13.5 \mathrm{~km}^{2}$ singleview pixel size (Warner et al., 2013). AIRS $\mathrm{NH}_{3}$ retrievals are based on the cloud-cleared radiances (CCRs) from AIRS L2 products. The averaging kernel (AK) peaks at about $918 \mathrm{hPa}$ giving AIRS good sensitivity to lower tropospheric $\mathrm{NH}_{3}$ because the planetary boundary layer generally extends above this altitude at the overpass local time of 1:30 p.m.

The algorithm used in this AIRS $\mathrm{NH}_{3}$ study was based on a retrieval module developed for AIRS carbon monoxide (CO) products (Warner et al., 2010). This module was built upon and added to the current AIRS operational system or team algorithm (Susskind et al., 2003), but used a different minimization method. The $\mathrm{NH}_{3}$ module uses AIRS Version 6 (V6) Level 2 (L2) profiles and errors from the previous retrieval steps (i.e., surface, clouds, water vapor, ozone, methane, $\mathrm{CO}$ ) as input to the AIRS forward model the stand-alone AIRS radiative transfer algorithm (SARTA) (Strow et al., 2003). We used SARTA with the addition of $\mathrm{NH}_{3}$ as a variable gas, which was carried out by co-author Strow and co-workers, since the official AIRS forward model does not include $\mathrm{NH}_{3}$ absorption as a variable. AIRS $\mathrm{NH}_{3}$ retrievals use an $\mathrm{OE}$ method following the formulations given by Rodgers (2000), and also described by Pan et al. (1998). The OE retrieval output quantities not only include the $\mathrm{NH}_{3}$ concentrations, but also provide the AKs, the error covariance, and the degrees of freedom for signal (DOFS), which benefit model verifications and data assimilation by using well-quantified errors.

Given a model of the instrument's signals, in the $\mathrm{OE}$ method, the forward equation for the $\mathrm{NH}_{3}$ profile retrieval problem can be written as

$\boldsymbol{y}=f(\boldsymbol{x}, \boldsymbol{b})+\boldsymbol{n}_{\varepsilon}$, where $\boldsymbol{y}$ is the vector of measured radiances, $\boldsymbol{x}$ is the state vector (variables to be retrieved from the measurements), $\boldsymbol{b}$ represents all other parameters used by the forward model, $f(\boldsymbol{x}, \boldsymbol{b})$ is the forward model function, and $\boldsymbol{n}_{\varepsilon}$ is the instrument noise. For the variables that obey a Gaussian distribution, this inverse problem is equivalent to the maximum likelihood solution. By using a Newtonian iteration; the solution to Eq. (1) can be written as (Rodgers, 2000)

$$
\begin{aligned}
\boldsymbol{x}_{n+1} & =\boldsymbol{x}_{\mathrm{a}}+\mathbf{C}_{\mathrm{a}} \mathbf{K}_{n}^{T}\left(\mathbf{K}_{n} \mathbf{C}_{\mathrm{a}} \mathbf{K}_{n}^{T}\right. \\
& \left.+\mathbf{C}_{\mathrm{e}}\right)^{-1}\left[\boldsymbol{y}-\boldsymbol{y}_{n}-\mathbf{K}_{n}\left(\boldsymbol{x}_{\mathrm{a}}-\boldsymbol{x}_{n}\right)\right]
\end{aligned}
$$

where $\boldsymbol{n}$ is the order of iteration and $\mathbf{C}_{\mathrm{e}}$ is the measurement error covariance matrix.

$\mathbf{K}_{n}=\partial f(\boldsymbol{x}, \boldsymbol{b}) / \partial \boldsymbol{x}$ is the jacobian matrix for iteration $\boldsymbol{n}$, which is the sensitivity matrix of the forward model to the state vector $\boldsymbol{x} . \boldsymbol{x}_{\mathrm{a}}$ is the mean of the a priori distribution and $\mathbf{C}_{\mathrm{a}}$ is the a priori error covariance matrix for $\boldsymbol{x}_{\mathrm{a}}$.

As defined by the retrieval formulations, the AKs are computed using the following equation:

$\mathbf{A}=\mathbf{C}_{\mathrm{a}} \mathbf{K}^{T}\left(\mathbf{K C}_{\mathrm{a}} \mathbf{K}^{T}+\mathbf{C}_{\mathrm{e}}\right)^{-1} \mathbf{K}$

and,

$\boldsymbol{x}^{\prime} \approx \mathbf{A} \boldsymbol{x}+(\mathbf{I}-\mathbf{A}) \boldsymbol{x}_{\mathrm{a}}$,

where $\mathbf{I}$ represents the identity matrix and $\boldsymbol{x}$ is the true state. Equation (4) states that in the absence of other error sources the retrieved state is a weighted mean of the true state and the a priori state, with the weight $\mathbf{A}$ for the true state and $\mathbf{I}-\mathbf{A}$ for the a priori. This shows the importance of AKs as diagnostics of the retrieval. The closer the matrix $\mathbf{A}$ is to the identity matrix the more the retrieved state resembles the true state.

The optimal estimation method requires an a priori mean profile and a corresponding error covariance matrix that represent the current knowledge of the geophysical property, i.e., $\mathrm{NH}_{3}$, prior to the retrieval. Due to the high spatial variability and short lifetime of $\mathrm{NH}_{3}$, a simple fixed a priori for all emission scenarios is not appropriate. We developed a global mean, multi-year averaged (2003-2012), three-tier a priori from GEOS-Chem model (v9-02) simulations for high, moderate, and low pollution. We used GEOS-5 MERRA data sets from the NASA Global Modeling and Assimilation Office (Rienecker et al., 2011) to drive the meteorological fields in the GEOS-Chem simulations. Figure 1 shows the a priori mean profiles (solid curve with squares) and the error covariance matrices (horizontal bars) for the low (left panel), the moderate (middle panel), and the high pollution (right panel), respectively. The high pollution range was defined by profiles with volume mixing ratios (VMRs) greater than or equal to 5 parts-per-billion-volume (ppbv) at the surface. The moderate pollution range includes the profiles with surface VMRs greater than or equal to $1 \mathrm{ppbv}$ but less than $5 \mathrm{ppbv}$, 

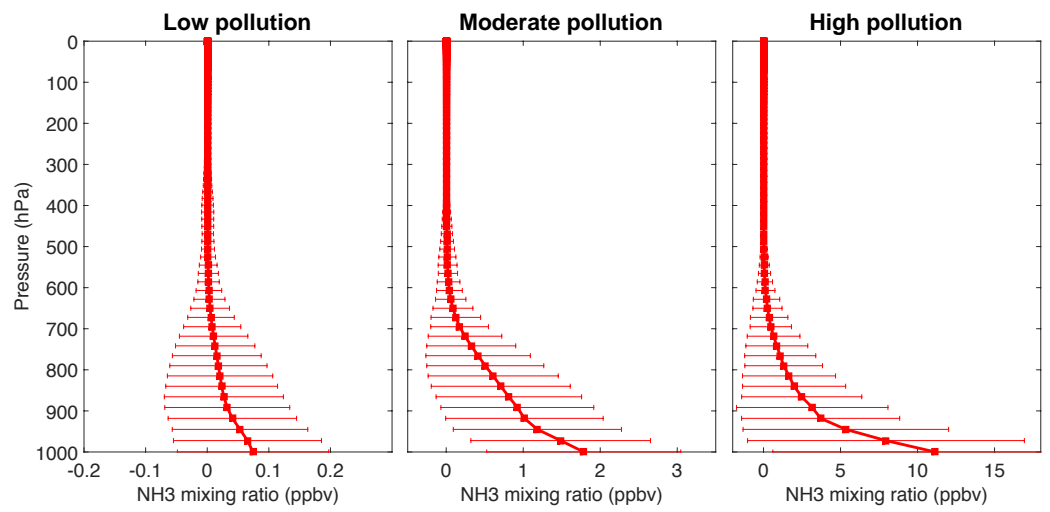

Figure 1. The a priori profiles and the square root of the diagonal terms of the error covariance matrices for the low pollution (left panel), the moderate pollution (middle panel), and the high pollution scenarios (right panel), respectively.

or greater than $1 \mathrm{ppbv}$ at any level between the surface and $500 \mathrm{hPa}$. The low pollution is then defined as being lower than the lower bounds of the moderate pollution range. The profiles were adjusted to match AIRS forward model levels. The modeled profiles are extrapolated near the surface with additional constraints to eliminate high values in the model near the surface, which are likely seen by satellite sensors.

The same set of the three-tier a priori profiles is used globally and throughout the AIRS data record. Thus, any spatial and temporal $\mathrm{NH}_{3}$ variations detected using this algorithm are from AIRS measurements. To select one of the three a priori profiles for each AIRS pixel, we examine the brightness temperature difference between a strong and a weak channel, divided by the measurement noise of the strong channel, defined as a "difference of brightness temperature index" (DBTI). This is similar to the method used by TES $\mathrm{NH}_{3}$ and described by Shephard et al. (2011). The DBTIs vary with meteorological conditions and, most importantly, the thermal contrast at the surface. To take these effects into account, we simulate the relationship between the brightness temperature differences and TC under various meteorological conditions using SARTA. We randomly picked 13790 profiles from AIRS L2 products over land from the months of January, April, July, and October in years 2003, 2008 , and 2011. We then perturbed the $\mathrm{NH}_{3}$ values spanning the three a priori mean profiles using the range of $0-100 \mathrm{ppbv}$ multiplied by a random number for each atmospheric profile. The observed brightness temperatures are compared with the simulated values at a given TC to determine the level of a priori for the full retrievals. Figure 2 depicts a relationship between the DBTI and DOFS for the three emission levels with low emissions in blue, moderate emissions in green, and high emissions in red. The higher DBTIs are correlated with higher DOFS, which represent higher surface thermal contrast (Deeter et al., 2007).

The $\mathrm{NH}_{3}$ retrieval quality assurance levels are determined based on the retrieval sensitivities under various meteorological and surface conditions using the AKs and the DOFS.

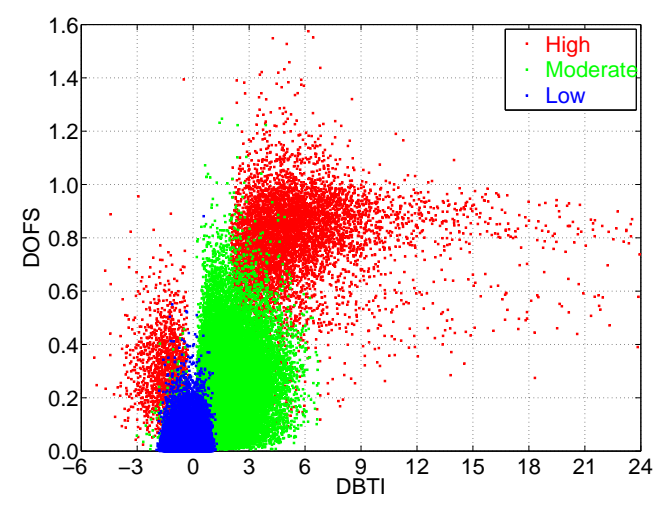

Figure 2. Correlation between the DBTI (difference of brightness temperature index) and DOFS (degrees of freedom for signal) for the three emission scenarios with low pollution in blue, moderate pollution in green, and high pollution in red.

We also take into account the performance of the retrievals against surface thermal contrasts from AIRS products. Additionally, we examine the retrieval residuals, $\chi^{2}$, and the number of iterations to set proper quality assurance flags. The retrieval residuals in Kelvin $(\mathrm{K})$ are defined by the square root of the mean variance of the observed brightness temperatures minus calculated. The $\mathrm{NH}_{3}$ retrieval quality is affected by the meteorological properties, such as the vertical temperature and water vapor profiles, surface temperatures, and emissivity, which are used to model the atmosphere. We also adapt the error information provided by the AIRS CCR for the relevant channels, which includes meteorological quantities that are used in deriving the AIRS CCR (http://disc.sci.gsfc.nasa.gov/AIRS/documentation/ v6_docs/v6releasedocs-1/V6_Level_2_Cloud_Cleared_ Radiances.pdf). This error information is flagged by Q0, Q1, and Q2 with Q0 having the highest quality and Q2 being unusable. In the remaining discussions of this study, we used $\chi^{2}$ between 0.9 and 27 , considering that the channels used 

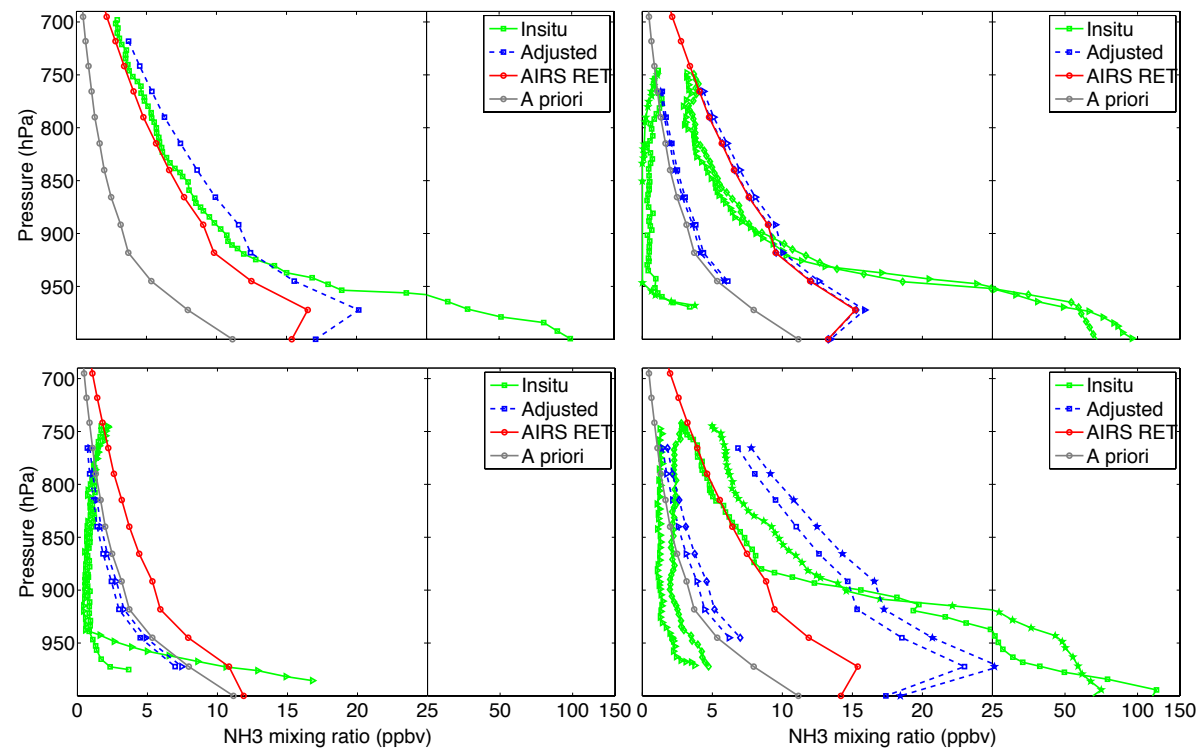

Figure 3. AIRS $\mathrm{NH}_{3}$ validation against CRDS (the cavity ring down spectrometer) spiral profiles collected during the DISCOVER-AQ CA (16 January-6 February 2013). The red curves represent AIRS retrieved profiles, gray curves are the a priori profiles, green solid lines are in situ spiral profiles, and the blue dashed lines are the convolved profiles using AIRS $\mathrm{NH}_{3}$ AKs. The $x$ axis is linear from 0 to 25 ppbv and logarithmic from 25 to $150 \mathrm{ppbv}$.

are not all spectrally independent. The number of iterations limit was set at 10 , meanwhile, only the cases with retrieval residuals less than $1 \mathrm{~K}$ are used. We also excluded cases with the surface thermal contrast between -4 and $+4 \mathrm{~K}$, to avoid ambiguous a priori levels; however, this primarily affects areas over the global oceans. Any additional screening of the data for higher quality requirements, e.g., the use of DOFS, will be discussed case by case. Although we have developed AIRS $\mathrm{NH}_{3}$ products for all available data sets, only the daytime and land cases are discussed in this study. Additionally, only radiances with quality flag as Q0 are selected for the discussions in the following sections to ensure the best accuracy.

\section{Validation with in situ measurements}

Validations of retrievals using in situ measurements are vital to quantifying uncertainties in the concentrations, sources, transport patterns, and trends using satellite data. Direct measurements of tropospheric $\mathrm{NH}_{3}$ are relatively sparse and in situ measurements above the ground level, necessary to validate satellite retrievals, are available for only limited locations and time periods (e.g. Nowak et al., 2007, 2010, 2012). Validation of AIRS $\mathrm{NH}_{3}$ data sets with available in situ measurements is a continuous effort as more in situ measurements become available. As an example of our validation effort, we use the DISCOVER-AQ $\mathrm{NH}_{3}$ measurements over California (https://www-air.larc.nasa.gov/ cgi-bin/ArcView/discover-aq.ca-2013). The sampling inlet and $\mathrm{NH}_{3}$ calibration set-up used during DISCOVER AQ with the cavity ring down spectrometer (CRDS) (G2103, Picarro Inc.) is the same as used with the Chemical Ionization Mass Spectrometry (CIMS) and described in Nowak et al. (2007). The CRDS, aboard the NASA P-3B aircraft during DISCOVER-AQ CA, data period covers 16 January to 6 February 2013. The in situ $\mathrm{NH}_{3}$ vertical profiles were made in the Southern San Joaquin Valley of California. This region inside the central valley of California, between the coastal mountains in the west and the Sierra Nevada Mountains in the east, consists largely of farmland with scattered dairy farms. Although most of the area is rural, the profiles were made near the small cities of Hanford and Corcoran. We only select spiral profiles from the flights within $45 \mathrm{~km}$ of the center of the retrieved AIRS profiles, for the closest match, and within $3 \mathrm{~h}$ of the measurement window, similar to the method used for AIRS CO validation (Warner et al., 2006).

Figure 3 shows four retrieval profiles that show high $\mathrm{NH}_{3}$ concentrations and meet the matching criteria, where the red curves represent AIRS retrieved profiles, gray curves are the a priori profiles, green solid lines are in situ spiral profiles, and the blue dashed lines are the convolved in situ profiles by AIRS $\mathrm{NH}_{3}$ AKs. The in situ spiral profiles are taken by flying an aircraft in the spiral shape in descending or ascending order near a central location, hence are the closest to being the true vertical profiles. Note that in Fig. 3, the $x$ axis is linear from 0 to $25 \mathrm{ppbv}$ and logarithmic from 25 to $150 \mathrm{ppbv}$. The convolved in situ profiles take into account satellite retrieval sensitivities, making them appropriate to compare against satellite retrievals (Rodgers and Connor, 2003). The convolution calculations follow Eqs. (3) and (4) in Sect. 2. The top 


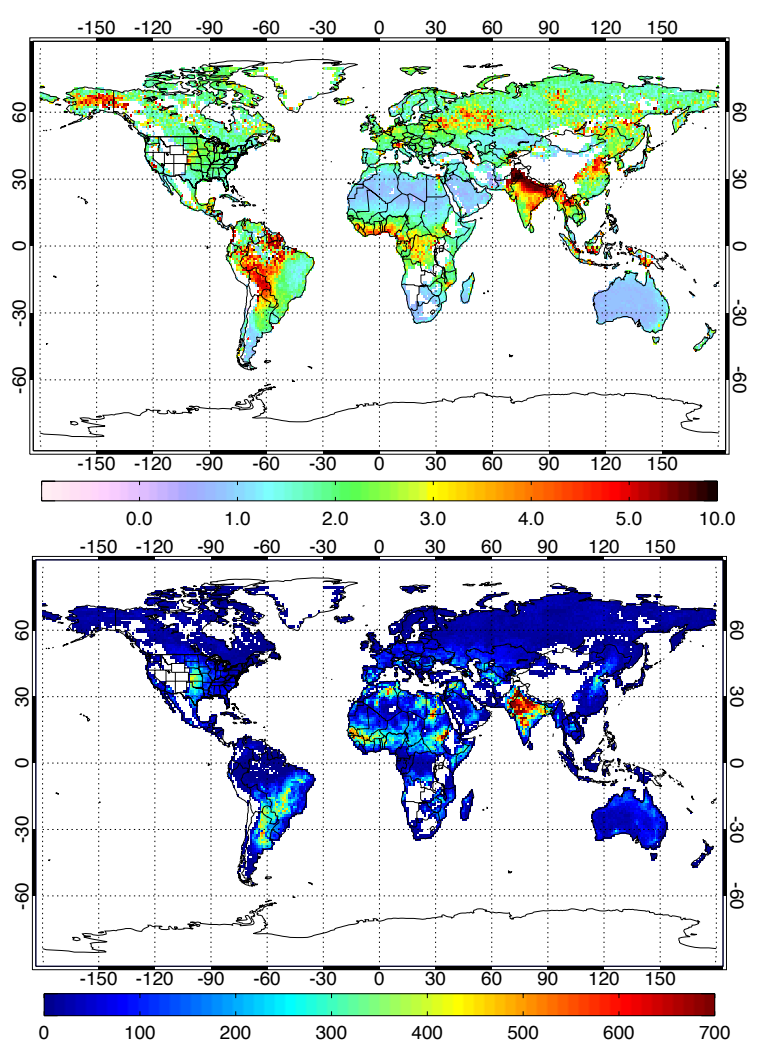

Figure 4. (upper panel) AIRS global $\mathrm{NH}_{3}$ VMRs at $918 \mathrm{hPa}$, averaged from September 2002 through August 2015. The colorbar is linear from 0 to 5 ppbv and 5 to $10 \mathrm{ppbv}$, but with different increments. (lower panel) The total occurrences (number of days) of high concentrations (VMRs $>1.0 \mathrm{ppbv}$ at $918 \mathrm{hPa}$ ) in the 13 -year period. Red/blue colors indicate relatively high/low occurrences of high concentrations, respectively.

left panel shows a case measured on 16 January 2013 with the retrieval quality at 0, DOFS at $0.64, \chi^{2}$ at 1.91 , the retrieval residual at $0.07 \mathrm{~K}$, and the measurement time differences at $1.31 \mathrm{~h}$. The distance between the in situ profile and the center of the AIRS profile is approximately $13.5 \mathrm{~km}$. The top right panel shows four in situ profiles from 21 January 2013 with AIRS retrieved profile quality at 0 , DOFS at $0.66, \chi^{2}$ at 1.26 , the retrieval residual at $0.07 \mathrm{~K}$, the time differences ranging from 0.58 to $1.68 \mathrm{~h}$, and the distance differences at approximately $56 \mathrm{~km}$ for all four profiles. The two profiles in the bottom left panel are also from 21 January 2013, with quality at 0, DOFS at $0.83, \chi^{2}$ at 0.31 , the retrieval residual at $0.06 \mathrm{~K}$. The time differences to the AIRS retrieved profile are 1.02 and $-1.25 \mathrm{~h}$, and the distances are 38.3 and $38.7 \mathrm{~km}$, respectively. In the bottom right panel, there are four profiles taken from 4 February 2013, with the retrieval profile quality at 0 , DOFS at $0.84, \chi^{2}$ at 1.1 , and the retrieval residual at $0.05 \mathrm{~K}$. The time differences between the in situ and the retrieved profiles are $1.63,1.40,-0.47$, and -0.71 , and the distances are 5.1, 45.2, 4.9, and $45.2 \mathrm{~km}$, respectively. Some

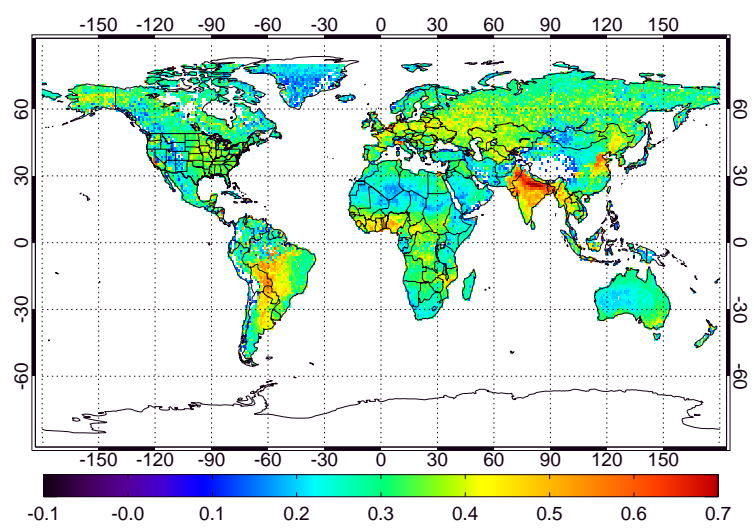

Figure 5. AIRS $\mathrm{NH}_{3}$ DOFS values averaged over September 2002August 2015 period. Red/blue colors indicate relatively high/low DOFS, respectively.

of the AIRS retrievals collocate with several in situ profiles, and these show substantial spatial variability.

Over regions with high $\mathrm{NH}_{3}$ in situ concentrations, the convolved in situ profiles agree with the retrievals within $>1$ to $\sim 3$ ppbv $(\sim 5-15 \%)$ near the top of the boundary layer, as seen in the top two panels in Fig. 3. These two AIRS $\mathrm{NH}_{3}$ profiles show good retrieval sensitivities with DOFS at approximately 0.64 and $0.66, \chi^{2}$ at 1.91 and 1.26 , and the residual at $0.07 \mathrm{~K}$, respectively. The top left in situ profile is relatively close $(13.5 \mathrm{~km})$ to the center of the AIRS pixel, whereas the top right in situ profiles are further away $(\sim 46 \mathrm{~km})$ from the center of the AIRS pixel. When the $\mathrm{NH}_{3}$ amount is low and there is very little sensitivity in AIRS measurements, the convolved profiles converge to the a priori profiles, as seen in the profiles with low $\mathrm{NH}_{3}$ concentrations in the top right panel and in the bottom left panel. In the bottom right panel, there are four in situ profiles close to the AIRS profile - the AIRS pixel measures the average effect of the area represented by the four in situ profiles. Below $925-950 \mathrm{hPa}$ in height, the in situ $\mathrm{NH}_{3}$ mixing ratios are significantly higher than the retrieved profiles, indicating a limitation of satellite remote sensing in capturing near surface composition properties. Note again that each AIRS profile covers a surface area of $45 \mathrm{~km}^{2}$ where in situ observed $\mathrm{NH}_{3}$ amounts can vary by a factor of ten. The aircraft in situ flights sometimes are biased by their proximity to strong local point sources. Therefore, the differences between the retrievals and in situ measurements are likely due to sampling issues, although the retrieved profile matches the average of the in situ profiles as discussed above. Nonetheless, the vertical profiles show good agreement $(\sim 5-15 \%)$ between AIRS $\mathrm{NH}_{3}$ and the in situ profiles in the examples given above. 


\section{Global ammonia concentrations}

The AIRS global $\mathrm{NH}_{3}$ VMRs at $918 \mathrm{hPa}$, averaged from September 2002 through August 2015, are shown in the upper panel of Fig. 4. The lower panel in Fig. 4 shows the total occurrences of elevated concentrations (VMRs $\geq 1.0 \mathrm{ppbv}$ at $918 \mathrm{hPa}$ ) for the same data set. The occurrences, in numbers of days, are good indicators of the types of emission sources either due to recurring agricultural practices or episodic forest fires. It is important to analyze the $\mathrm{NH}_{3}$ VMRs together with the occurrences to identify major emission sources. Another important quantity used in the $\mathrm{NH}_{3}$ source analysis is the retrieval DOFS. Figure 5 shows the AIRS $\mathrm{NH}_{3}$ DOFS values being in a range of 0.1 to slightly above 1.0. The regions with DOFS greater than 0.4 are generally associated with high $\mathrm{NH}_{3}$ concentrations and strong signal to noise ratios. We used a threshold level of DOFS of 0.1 to screen the retrievals in the Fig. 4 top panel to eliminate noise and to focus on where AIRS sensitivity is high. Areas with DOFS $<0.1$ in the whole data record are indicated in white. The AIRS retrievals are sensitive to $\mathrm{NH}_{3}$ concentrations in the lowest layer of the atmosphere between $850 \mathrm{hPa}$ and the surface, with sensitivity peaking at approximately $918 \mathrm{hPa}$ based on the retrieved AKs (not shown). Therefore, we use $\mathrm{NH}_{3}$ VMRs at this level for all discussions in this study. There are diurnal variations in the data sets (not shown) that may be due to a number of factors including the day-night differences of emissions and chemical reactions and possibly measurement sensitivities, which are beyond the scope of this paper and will be studied at a later time. Also note that the missing data over land in certain regions are either due to high elevation (above the $918 \mathrm{hPa}$ altitude level), and therefore not shown, or persistent cloudy days.

Globally, AIRS shows strong $\mathrm{NH}_{3}$ hotspots from biogenic and anthropogenic sources including South Asia (India/Pakistan), East Asia (China), the central US, parts of Europe, Southeast Asia (Thailand/Myanmar/Laos), the central portion of South America, and Western and Northern Africa, where both the $\mathrm{NH}_{3}$ VMRs and the frequent occurrences are high. The primary sources for these regions are from human activities, e.g., livestock waste management and other agricultural activities. The $\mathrm{NH}_{3}$ concentrations over these hot spots vary from $\sim 2.5$ to above $10 \mathrm{ppbv}$, averaged over 13 years covering both strong and weak emission periods. Also seen are large regions of high $\mathrm{NH}_{3}$ concentrations due to biomass burning events over Russia, Alaska, South America, Africa, and Indonesia, represented by high VMRs and low occurrences. High concentrations of $\mathrm{NH}_{3}$ are persistent over South America and reflect emissions from biomass burning that are trapped by the Andes http://earthobservatory.nasa.gov/IOTD/view.php? id $=8033 \&$ eocn $=$ image\&eoci=related_image. The hot spot over South Asia corresponds to the heavily populated IndoGangetic Plain with plentiful, fertile croplands and extensive livestock, and bounded on the north by the Himalayas (Ya-

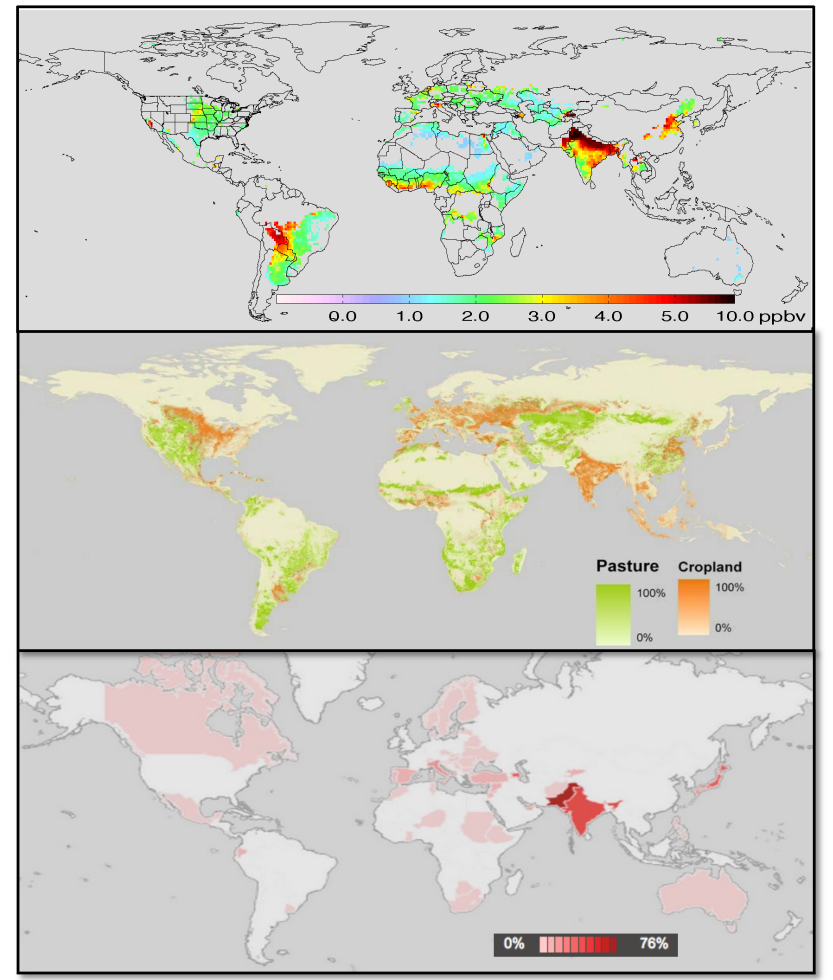

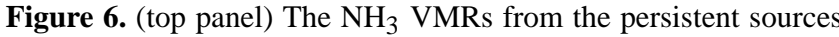
filtered with the collocated occurrences of elevated concentrations $(\geq 1.4 \mathrm{ppbv}$ ) using a threshold of greater than 40 days; (middle panel) pasture and Cropland Map (http://OurWorldInData.org); and (bottom panel) irrigated agricultural land areas (http://data. worldbank.org). Footnote: The World Bank provided the statement that the maps displayed on the World Bank web site are for reference only and do not imply any judgment on the legal status of any territory, or any endorsement or acceptance of such boundaries.

maji et al., 2004). The absolute maximum on Fig. 4 is found over the Punjab which has the highest population density in Pakistan.

To understand the persistent emission sources, we filtered the $\mathrm{NH}_{3}$ VMRs with the collocated occurrences of elevated concentrations ( $\geq 1.4 \mathrm{ppbv}$ ) greater than 40 days; and the results are shown in Fig. 6 top panel. Although a sufficient concentration ( $\geq 1.4 \mathrm{ppbv}$ ) threshold is used to calculate occurrences of the persistent sources, we used all VMR values, with DOFS greater than 0.1, for the VMR maps. The persistent $\mathrm{NH}_{3}$ sources not only include those large regions listed above, but also include small geographical areas such as in the San Joaquin Valley of central California in the US (with low sulfur emissions and where livestock are plentiful); the Po Valley, Italy; Fergana Valley, Uzbekistan; Azerbaijan; the Nile Delta and along the banks of the Nile River in Egypt; and the Sichuan Basin in China. Some of these source locations are consistent with those previously reported by Clarisse et al. (2009). These emission hotspots are compared with the "Pasture and Cropland Map" (see middle panel in 

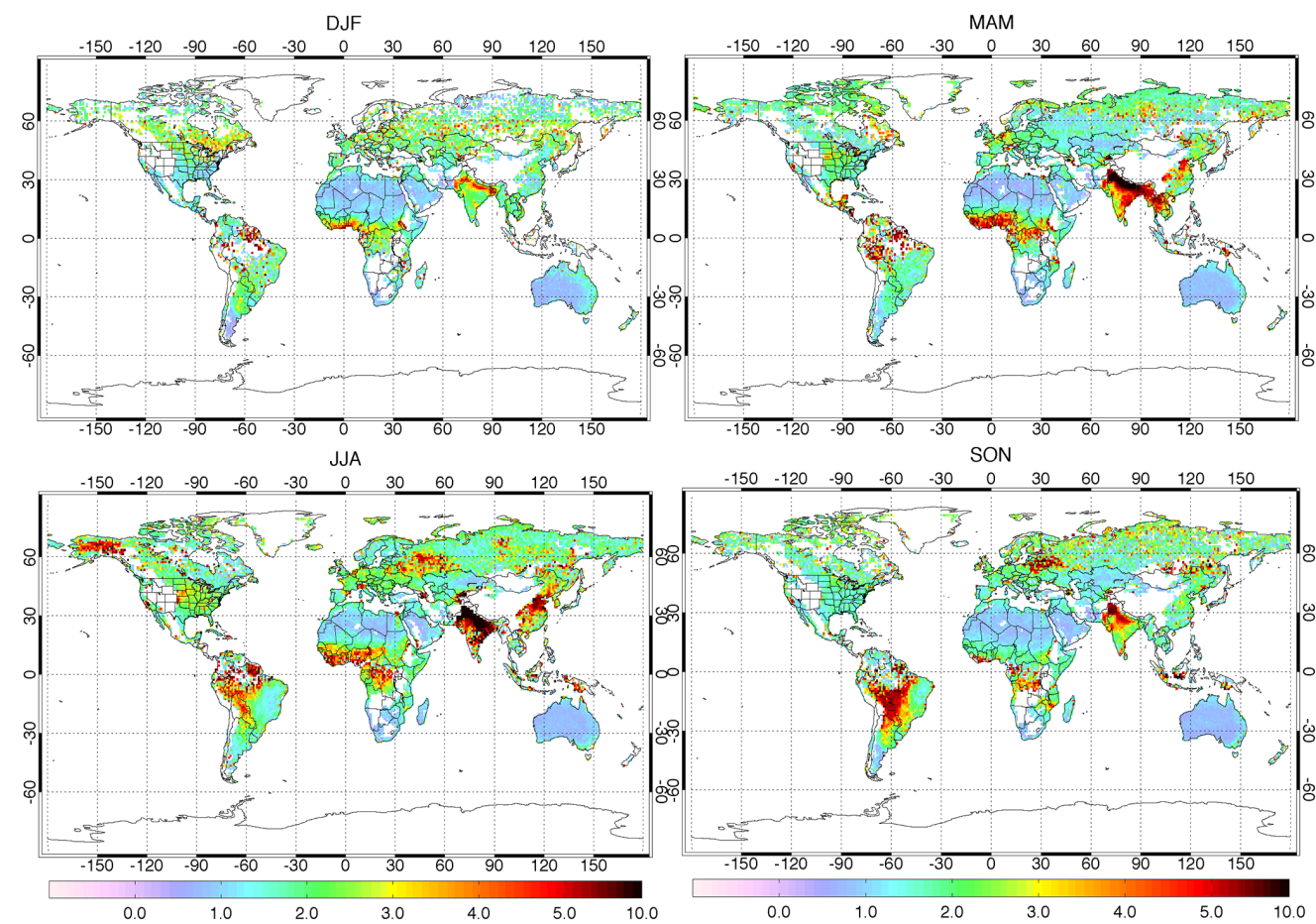

Figure 7. AIRS $\mathrm{NH}_{3}$ VMRs at $918 \mathrm{hPa}$ averaged between September 2002 and August 2015 for December-January-February (DJF, upper left panel), March-April-May (MAM, upper right panel), June-July-August (JJA, lower left panel), and September-October-November (SON, lower right panel), with DOFS greater than 0.1 and no cutoff limit for the VMRs. Red/purple colors indicate relatively high/low $\mathrm{NH}_{3}$ VMRs.
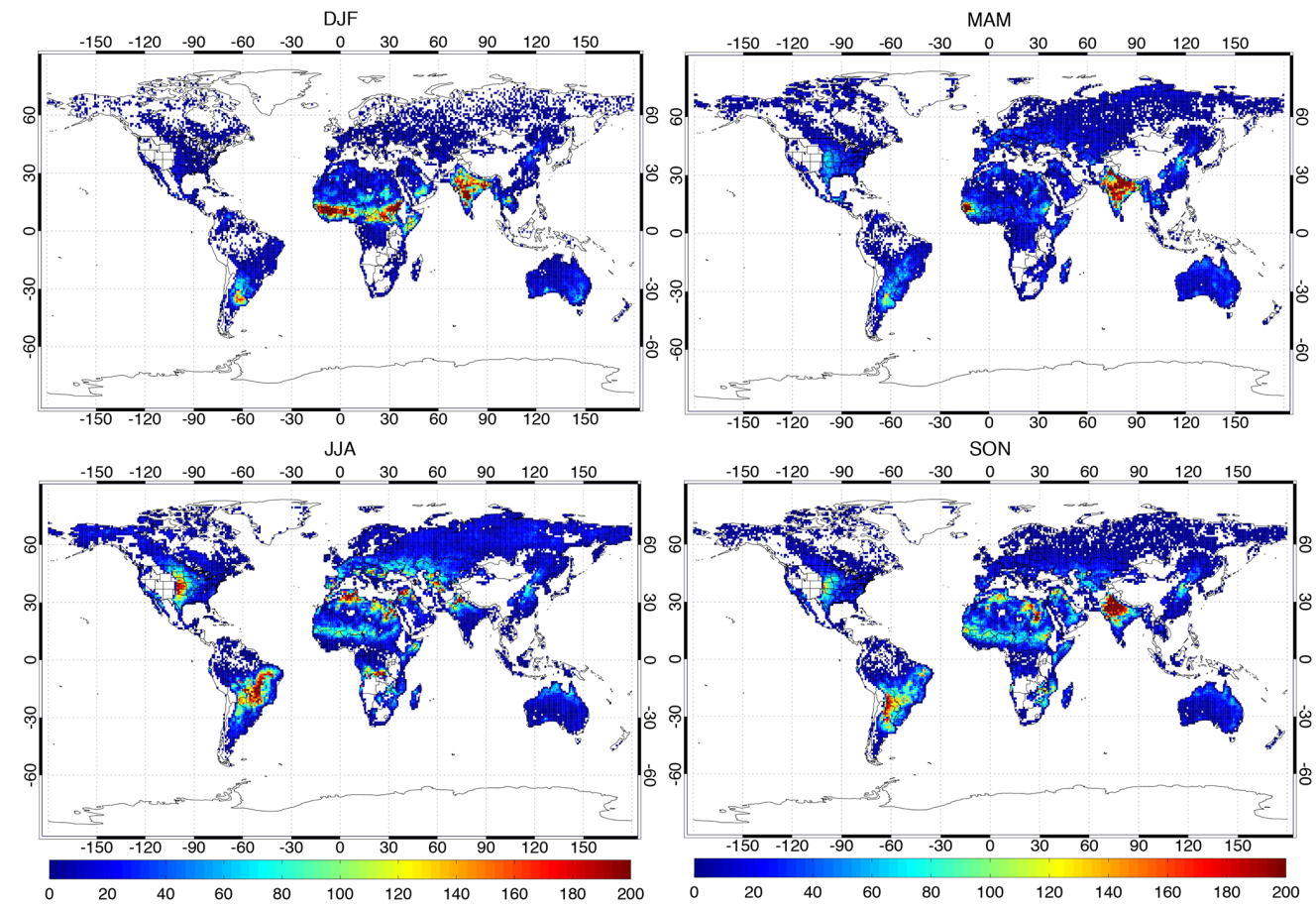

Figure 8. As in Fig. 7 except for the occurrences of high concentrations (VMRs $\geq 1$ ppbv). Red/blue colors indicate relatively high/low occurrences of high concentrations. 
Fig. 6), posted by http://OurWorldInData.org, located at the Institute for New Economic Thinking at the Oxford Martin School. AIRS $\mathrm{NH}_{3}$ source regions are strongly correlated with cropland areas, e.g., over India, China, the middle US, Western Africa, eastern South America, and Europe. Note that four of the strongest emission regions correspond to high percentage irrigated agricultural areas (see bottom panel in Fig. 6), i.e., over Pakistan, India, northern Italy, and Azerbaijan adjacent to the Caspian Sea. The irrigated agricultural land includes that irrigated by controlled flooding. These data are provided by the World Bank (http://data.worldbank.org) where the color values are the percent agricultural irrigated land of total agricultural land. These irrigation activities are associated with periods of fertilization and ammonia release. Sommer et al. (2004) studied the relationship between the fertilizing time and the ammonia release time and indicated that the fertilizers applied in March can be released in the June to August time frame depending on the amount of precipitation. The irrigation practices may have the same effect as high amounts of precipitation.

Over China, the AIRS retrieval can match high-resolution inventories distinguishing the two major animal husbandry areas in east-central China (Henan, Shandong, and Hebei provinces) as well as Sichuan to the southwest (Huang et al., 2012). Additional weaker, but persistent, $\mathrm{NH}_{3}$ sources are also seen in the Fig. 6 top panel that are likely related to livestock and agriculture practices. These source regions include areas in eastern North Carolina (consistent with Wu et al., 2007), Arizona near Phoenix, in the east coast of Spain near Barcelona and Águilas, and over large areas in the Netherlands, in Mozambique in Africa, and the Gambela National Park region between Ethiopia and South Sudan.

\section{Seasonal variability}

Seasonal variations are shown in Fig. 7 in the four $\mathrm{NH}_{3}$ VMR maps, averaged between September 2002 and August 2015, for December-January-February (DJF, upper left panel), March-April-May (MAM, upper right panel), June-July-August (JJA, lower left panel), and SeptemberOctober-November (SON, lower right panel), respectively, with DOFS greater than 0.1 and no cutoff for the VMRs. Globally, the highest concentrations are in the $\mathrm{NH}$ summer and spring seasons, with the exception from strong biomass burning (BB) sources, i.e., over South America, Southeast Asia, and Russia in the $\mathrm{NH}$ fall season. The highest $\mathrm{NH}_{3}$ concentrations over non-BB dominant regions occur over India, China, the Mid-West US, and parts of Europe in the summer months. The longest high concentration seasons are over northern India, collocated with the measurement of high $\mathrm{NH}_{4}^{+}$in the precipitation over India reported by Kulshrestha et al. (2005). The seasonal $\mathrm{NH}_{3}$ VMR distributions in China, Europe, and the US are also consistent, to a large extent, with the Paulot et al. (2014) study of agricultural emissions in-
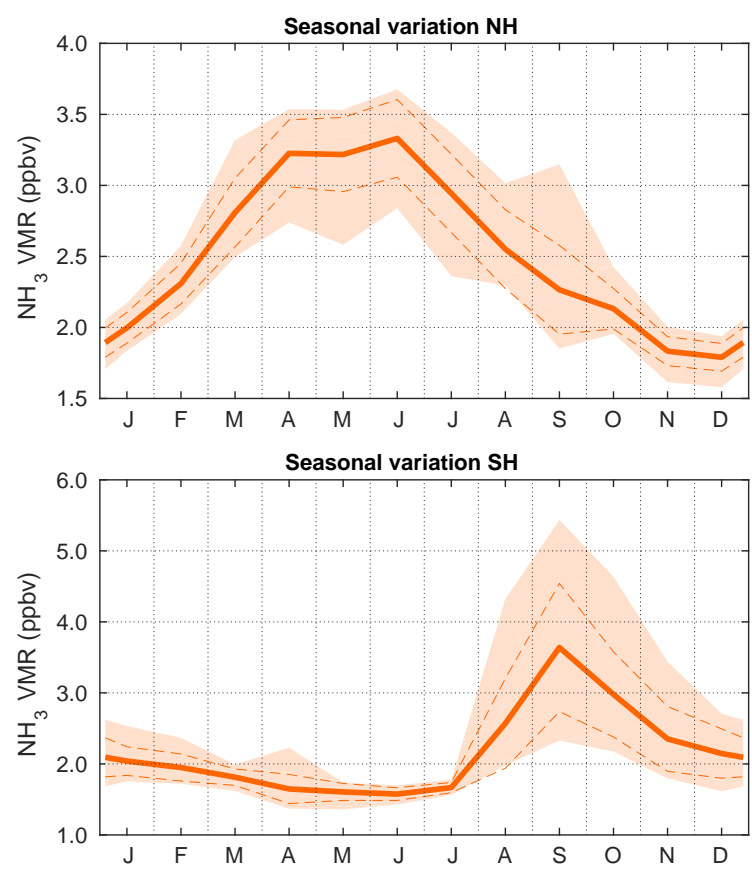

Figure 9. The $\mathrm{NH}_{3}$ monthly mean variations (solid line) in the $\mathrm{NH}$ (upper panel) and the SH (lower panel), respectively. The long-dash lines show the $1 \sigma$ standard deviation (SD); and the shaded areas represent the maximum and minimum range of each data set.

ventory derived by high-resolution inversion of ammonium wet deposition data. This is especially true for the spring season, as seen in Fig. A1 of Paulot et al. (2014), showing MASAGE_NH3 (Magnitude and Seasonality of Agricultural Emissions for $\mathrm{NH}_{3}$ ) emissions of $\mathrm{NH}_{3}$ from fertilizers.

High average concentrations (Fig. 7) with low frequencies of occurrences (Fig. 8) generally indicate $\mathrm{NH}_{3}$ from biomass burning (BB). The greatest emissions from $\mathrm{BB}$ in the $\mathrm{NH}$ appear in the summer months over Siberia and eastern Russia as well as over Alaska, US. The highest concentrations due to BB in the SH appear over South America in September to November (spring for the $\mathrm{SH}$ ) when precipitation is minimal and burning extensive (Oliveras et al., 2014). Over SE Asia where the dry season and most BB occur in March to May, we find another local maximum (Lin et al., 2013). Over Africa high concentrations from BB occur in the Western and Central regions, although both high concentrations and frequencies of occurrences appear in the Sahel just south of the Sahara in the NH winter. In that region persistent burning of agricultural waste has been reported (Haywood et al., 2008); see also http://rapidfire.sci.gsfc.nasa.gov/cgi-bin/ imagery/firemaps.cgi.

Ammonia seasonal variations are presented (Fig. 9) using the monthly mean VMRs averaged over the 13-year period. Simple hemispheric averages of $\mathrm{NH}_{3}$ concentrations for all cases do not accurately reflect the seasonality of the important agricultural activities in the $\mathrm{NH}$, due to the mixing 
with $\mathrm{BB}$ cases and low $\mathrm{NH}_{3}$ regions, as well as regions with missing values due to weeks of persistent cloud cover. To understand how $\mathrm{NH}_{3}$ emissions vary seasonally due to human activities, we focus on the $\mathrm{NH}_{3}$ concentrations from the continuous emission sources. As in the case of Fig. 6, where we showed continuous sources using screening by the occurrences of elevated concentrations, we select the occurrence thresholds at concentration levels higher than $1.4 \mathrm{ppbv}$ on at least 40 days of the 13-year record. Figure 9 shows the monthly mean variations of $\mathrm{NH}_{3}$ (solid line) in both the $\mathrm{NH}$ (upper panel) and the SH (lower panel); the dashed lines show the $\pm 1 \sigma$ (standard deviation, SD) and the shaded areas represent the maximum and minimum range of each data set. In the NH, the high emission period starts in April and the $\mathrm{NH}_{3}$ concentrations peak in June. The $\mathrm{NH}$ average of the VMR concentrations from April through July is in the range of 3.7-4.0 ppbv; and it gradually decreases to the minimum of below 2 ppbv in November-December-January. The range of monthly mean variability between different years is also larger from April to September (at $\sim 1$ ppbv) than in the winter months (at $\sim 0.4 \mathrm{ppbv}$ ). The SD decreases from the summer values of 0.6 to $0.3 \mathrm{ppbv}$ in the winter.

Seasonal variation in the SH (lower panel in Fig. 9) shows that the primary sources of $\mathrm{NH}_{3}$ emission are from $\mathrm{BB}$, as was seen in the $\mathrm{NH}_{3}$ seasonal maps (e.g., Fig. 7). Although the filtering for the continuous emission sources eliminated some large occasional fires (i.e., over Indonesia), there are still regularly occurring fires, such as those over the central part of South America. The $\mathrm{NH}_{3}$ concentrations in the $\mathrm{SH}$ peaks in September with an average value near $3.5 \mathrm{ppbv}$ and decreases sharply after the SH spring season. The season of high concentrations in the $\mathrm{SH}$ is much shorter than in the $\mathrm{NH}$, as demonstrated by the widths of the seasonal distribution curves. The largest SD occurs in September with a magnitude of $2 \mathrm{ppbv}$, but the variation between different years in the winter is very small $(\sim 0.25 \mathrm{ppbv})$.

\section{Summary}

The AIRS ammonia $\left(\mathrm{NH}_{3}\right)$ measurements with a 13-year data record provide global daily maps, identify major source regions, and show seasonal cycles. This enables studies for detailed locations of the sources and their spatial and temporal variations. The AIRS $\mathrm{NH}_{3}$ products using the optimal estimation (OE) retrievals provide retrieval sensitivity properties, in addition to $\mathrm{NH}_{3}$ concentrations, such as the averaging kernels (AKs), error covariance matrices, and the degrees of freedom for signal (DOFS). This will facilitate sensor inter-comparisons, model verifications, and data assimilation of satellite retrievals. AIRS measurements can not only capture high biomass burning emissions (e.g., over Russia, Alaska, South America, Africa, and Indonesia) and/or accumulated concentrations such as in various valleys (e.g., San Joaquin Valley, California in the US, the Po Valley, Italy, Fer- gana Valley, Uzbekistan, and the Sichuan Basin in China), but also emissions due to routine animal feeding and agriculture activities (e.g., Azerbaijan, Nile Delta and along the banks of the Nile River in Egypt, the Mid-West US, North Carolina, US, the east coast of Spain, in the Netherlands, in Mozambique and Ethiopia, Africa, and especially the IndoGangetic Plain of South Asia). Over China, the AIRS retrieval can match high-resolution inventories distinguishing the two major animal husbandry areas in east-central China and the Sichuan Basin. Preliminary validation results show excellent agreement with in situ airborne measurements (to within $5-15 \%$ of the retrieved profiles). Note that since each AIRS profile covers a surface area of $45 \mathrm{~km}^{2}$ where the $\mathrm{NH}_{3}$ amounts can vary largely, the simple numerical differences may not be the optimal way to validate satellite ammonia products.

We use frequent occurrences of $\mathrm{NH}_{3}$ elevated concentrations to select persistent sources. This distinguishes the $\mathrm{NH}_{3}$ emissions due to human activities versus occasional fires or retrieval noise. We show the persistent ammonia sources correlate well with cropland usage, particularly in regions where irrigation is a routine practice. We show that the hemispheric seasonal variation using sources screened by the high $\mathrm{NH}_{3}$ frequent occurrences. The $\mathrm{NH}$ high $\mathrm{NH}_{3}$ concentrations occur in the spring and summer with highest from April to July and lowest in November through January. In the $\mathrm{SH}$, the $\mathrm{NH}_{3}$ concentration is highest in September, this is most likely due to BB emissions shown by the high VRMs and relatively low frequent occurrences.

Detailed examinations of specific regions are needed and will be included in future studies to improve our understanding of the processes that control the $\mathrm{NH}_{3}$ distribution and variability. The recent $\mathrm{NH}_{3}$ trends from AIRS 13-year measurements will also be a subject of future studies since the scope of this paper is to focus on the algorithm details and the global distributions. Results in this study are focused on land and daytime only. Future studies will include more complicated surface types, i.e., ocean surfaces and regions with lower thermal contrast. The diurnal variations will also be an important topic in the future studies. We have used the pixels with the highest quality cloud-cleared radiances (at $45 \mathrm{~km}^{2}$ spatial resolution) defined by the earlier steps of AIRS retrievals, while a future direction will be to also use the higher spatial resolution single-view pixels (at $13.5 \mathrm{~km}^{2}$ ) under clear-sky conditions (Warner et al., 2013).

\section{Data availability}

Data used for this study are included in the first author Warner's webpage (http://www.atmos.umd.edu/ juying/ ACP_2015_819/) under Data Links.

Acknowledgements. This study was funded by NASA's The Science of Terra and Aqua program under grant numbers NNX11AG39G and NNX12AJ05G. We wish to acknowledge the 
GEOS-Chem team, AIRS science team, DISCOVER-AQ team. MERRA data used in this study/project have been provided by GMAO at NASA Goddard Space Flight Center through the NASA GES DISC online archive. Resources supporting this work were provided by the NASA High-End Computing (HEC) Program through the NASA Center for Climate Simulation (NCCS) at Goddard Space Flight Center.

Edited by: W. Lahoz

\section{References}

Abbatt, J. P. D., Benz, S., Cziczo, D. J., Kanji, Z., Lohmann, U., and Mohler, O.: Solid Ammonium Sulphate Aerosols as Ice Nuclei: A Pathway for Cirrus Cloud Formation, Science, 313, 17701773, 2006.

Adams, P. J., Seinfeld, J. H., and Koch, D. M.: Global concentrations of tropospheric sulfate, nitrate, and ammonium aerosol simulated in a general circulation model, J. Geophys. Res.-Atmos., 104, 13791-13823, 1999.

Adams, P. J., Seinfeld, J. H., Koch, D., Mickley, L., and Jacob, D.: General circulation model assessment of direct radiative forcing by the sulfate-nitrate-ammonium-water inorganic aerosol system, J. Geophys. Res.-Atmos., 106, 1097-1111, doi:10.1029/2000JD900512, 2001.

Alvarado, M. J., Cady-Pereira, K. E., Xiao, Y., Millet, D. B., and Payne, V. H.: Emission Ratios for Ammonia and Formic Acid and Observations of Peroxy Acetyl Nitrate (PAN) and Ethylene in Biomass Burning Smoke as Seen by the Tropospheric Emission Spectrometer (TES), Atmosphere, 2, 633-654, doi:10.3390/atmos2040633, 2011.

Andreae, M. O. and Merlet, P.: Emissions of trace gases and aerosols from biomass burning, Global Biogeochem. Cy., 15, 955-966, 2001.

Aneja, V. P., Chauhan, J. P., and Walker, J. T.: Characterization of atmospheric ammonia emissions from swine waste storage and treatment lagoons, J. Geophys. Res., 105, 11535-11545, 2000.

Beer, R., Shephard, M. W., Kulawik, S. S., Clough, S. A., Eldering, A., Bowman, K. W., Sander, S. P., Fisher, B. M., Payne, V. H., Luo, M., Osterman, G. B., and Worden, J. R.: First satellite observations of lower tropospheric ammonia and methanol, Geophys. Res. Lett., 35, L09801, doi:10.1029/2008GL033642, 2008.

Bey, L., Jacob, D. J., Yantosca, R. M., Logan, J. A., Field, B., Fiore, A. M., Li, Q., Liu, H., Mickley, L. J., and Schultz, M.: Global modeling of tropospheric chemistry with assimilated meteorology: Model description and evaluation, J. Geophys. Res., 106, 23073-23096, 2001.

Bouwman, A. F., Lee, D. S., Asman, W. A. H., Dentener, F. J., VanderHoek, K. W., and Olivier J. G. J.: A global high-resolution emission inventory for ammonia, Global Biogeochem. Cy., 11, 561-587, doi:10.1029/97GB02266, 1997.

Clarisse, L., Clerbaux, C., Dentener, F., Hurtmans, D., and Coheur, P.-F.: Global ammonia distribution derived from infrared satellite observations, Nat. Geosci., 2, 479-483, doi:10.1038/ngeo551, 2009

Clarisse, L., Shephard, M. W., Dentener, F., Hurtmans, D., CadyPereira, K., Karagulian, F., Damme, M. V., Clerbaux, C., and Coheur P.-F.: Satellite monitoring of ammonia: A case study of the San Joaquin Valley, J. Geophys. Res., 115, D13302, doi:10.1029/2009JD013291, 2010.

Coheur, P.-F., Clarisse, L., Turquety, S., Hurtmans, D., and Clerbaux, C.: IASI measurements of reactive trace species in biomass burning plumes, Atmos. Chem. Phys., 9, 5655-5667, doi:10.5194/acp-9-5655-2009, 2009.

Crawford, J. H., Dickerson, R. R., and Hains, J. C.: DISCOVERAQ: Observations and early results, Environ. Manage., available at: http://awma.org, last access: September 2014.

Deeter, M. N., Edwards, D. P., Gille, J. C., and Drummond, J. R.: Sensitivity of MOPITT observations to carbon monoxide in the lower troposphere, J. Geophys. Res., 112, D24306, doi:10.1029/2007JD008929, 2007.

Duncan, B. N., Martin, R. V., Staudt, A. C., Yevich, R., and Logan, J. A.: Interannual and seasonal variability of biomass burning emissions constrained by satellite observations, J. Geophys. Res., 108, 4100, doi:10.1029/2002JD002378, 2003.

EPA: Reactive Nitrogen in the United States, A Report to the EPA Science Advisory Board, 164 pp., available at: http://yosemite.epa.gov/sab/ sabproduct.nsf/02ad90b136fc21ef85256eba00436459/ c83c30afa4656bea85256ea10047e1e1! OpenDocument\&TableRow=2.2 (11/5/10 Draft), 2011.

Erisman, J. W., Galloway, J. N., Seitzinger, S., Bleeker, A., Dise, N. B., Petrescu, R., Leach, A. M., and de Vries, W.: Consequences of human modification of the global nitrogen cycle, Philos. T. R. Soc. B, 368, 1621, doi:10.1098/rstb.2013.0116, 2013.

Fowler, D., Pilegaard, K., Sutton, M. A., Ambus, P., Raivonen, M., Duyzer, J., Simpson, D., Fagerli, H., Fuzzi, S., Schjoerring, J. K., Granier, C., Neftel, A., Isaksen, I. S. A., Laj, P., Maione, M., Monks, P. S., Burkhardt, J., Daemmgen, U., Neirynck, J., Personne, E., Wichink-Kruit, R., Butterbach-Bahl, K., Flechard, C., Tuovinen, J. P., Coyle, M., Gerosa, G., Loubet, B., Altimir, N., Gruenhage, L., Ammann, C., Cieslik, S., Paoletti, E., Mikkelsen, T. N., Ro-Poulsen, H., Cellier, P., Cape, J. N., Horvath, L., Loreto, F., Niinemets, U., Palmer, P. I., Rinne, J., Misztal, P., Nemitz, E., and Nilsso, D.: Atmospheric composition change: Ecosystems-Atmosphere interactions, Atmos. Environ., 43, 5193-5267, 2009.

Galloway, J. N., Townsend, A. R., Erisman, J. W., Bekunda, M., Cai, Z., Freney, J. R., Martinelli, L. A., Seitzinger, S. P., and Sutton, M. A.: Transformation of the nitrogen cycle: Recent trends, questions, and potential solutions, Science, 320, 889-892, 2008.

Haywood, J. M., Pelon, J., Formenti, P., Bharmal, N. A., Brooks, M. E., Capes, G., Chazette, P., Chou, C., Christopher, S. A., and Coe, H.: Overview of the Dust and Biomass-burning Experiment and African Monsoon Multidisciplinary Analysis Special Observing Period-0, J. Geophys. Res., 113, D00C17, doi:10.1029/2008JD010077, 2008.

Heald, C. L., Collett Jr., J. L., Lee, T., Benedict, K. B., Schwandner, F. M., Li, Y., Clarisse, L., Hurtmans, D. R., Van Damme, M., Clerbaux, C., Coheur, P.-F., Philip, S., Martin, R. V., and Pye, H. O. T.: Atmospheric ammonia and particulate inorganic nitrogen over the United States, Atmos. Chem. Phys., 12, 10295-10312, doi:10.5194/acp-12-10295-2012, 2012.

Henze, D. K., Hakami, A., and Seinfeld, J. H.: Development of the adjoint of GEOS-Chem, Atmos. Chem. Phys., 7, 2413-2433, doi:10.5194/acp-7-2413-2007, 2007. 
Henze, D. K., Shindell, D. T., Akhtar, F., Spurr, R. J. D., Pinder, R. W., Loughlin, D., Kopacz, M., Sing, K., and Shim, C.: Spatially refined aerosol direct radiative forcing efficiencies, Environ. Sci. Technol., 46, 9511-9518, doi:10.1021/es301993s, 2012.

Huang, X., Song, Y., Li, M., Li, J., Huo, Q., Cai, X., Zhu, T., Hu, M., and Zhang, H.: A high-resolution ammonia emission inventory in China, Global Biogeochem. Cy., 26, GB1030, doi:10.1029/2011GB004161, 2012.

Kulshrestha, U. C., Granat, L., Engardt, M., and Rodhe, H.: Review of precipitation monitoring studies in India - a search for regional patterns, Atmos. Environ., 39, 4419-4435, 2005.

Lin, N. H., Tsay, S. C., Maring, H. B., Yen, M.-C., Sheu, G.-C., Wang, S.-H., Chi, K. H., Chuang, M.-T., Ou-Yang, C.-F., Fu, J. S., Reid, J. S., Lee, C.-T., Wang, L.-C., Wang, J.-L., Hsu, C. N., Sayer, A. M., Holben, B. N., Chu, Y.-C., Nguyen, X. C., Sopajaree, K., Chen, S.-J., Cheng, M.-T., Tsuang, B.-J., Tsai, C.J., Peng, C.-M., Schnell, R. C., Conway, T., Chang, C.-T., Lin, K.-S., Tsai, Y. I., Lee, W.-J., Chang, S.-C., Liu, J.-J., Chiang, W.-L., Huang, S.-J., Lin, T.-H., and Liu, G.-R.: An overview of regional experiments on biomass burning aerosols and related pollutants in Southeast Asia: From BASE-ASIA and the Dongsha Experiment to 7-SEAS, Atmos. Environ., 78, 1-19, doi:10.1016/j.atmosenv.2013.04.066, 2013.

Luo, M., Shephard, M. W., Cady-Pereira, K. E., Henze, D. K., Zhu, L., Bash, J. O., Pinder, R. W., Capps, S. L., Walker, J. T., and Jones, M. R.: Satellite observations of tropospheric ammonia and carbon monoxide: Global distributions, regional correlations and comparisons to model simulations, Atmos. Environ., 106, 262e277, doi:10.1016/j.atmosenv.2015.02.007, 2015.

Malm, W. C., Schichtel, B. A., Pitchford, M. L., Ashbaugh, L. L., and Eldred, R. A.: Spatial and monthly trends in speciated fine particle concentration in the United States, J. Geophys. Res., 109, D03306, doi:10.1029/2003JD003739, 2004.

Martin, S. T., Hung, H.-M., Park, R. J., Jacob, D. J., Spurr, R. J. D., Chance, K. V., and Chin, M.: Effects of the physical state of tropospheric ammonium-sulfate-nitrate particles on global aerosol direct radiative forcing, Atmos. Chem. Phys., 4, 183214, doi:10.5194/acp-4-183-2004, 2004.

Nowak, J. B., Neuman, J. A., Kozai, K., Huey, L. G., Tanner, D. J., Holloway, J. S., Ryerson, T. B., Frost, G. J., McKeen, S. A., and Fehsenfeld, F. C.: A chemical ionization mass spectrometry technique for airborne measurements of ammonia, J. Geophys. Res., 112, D10S02, doi:10.1029/2006JD007589, 2007.

Nowak, J. B., Neuman, J. A., Bahreini, R., Brock, C. A., Middlebrook, A. M., Wollny, A. G., Holloway, J. S., Peischl, J., Ryerson, T. B., and Fehsenfeld, F. C.: Airborne observations of ammonia and ammonium nitrate formation over Houston, TX, J. Geophys. Res., 115, D22304, doi:10.1029/2010JD014195, 2010.

Nowak, J. B., Neuman, J. A., Bahreini, R., Middlebrook, A. M., Holloway, J. S., McKeen, S. A., Parrish, D. D., Ryerson, T. B., and Trainer, M.: Ammonia sources in the California South Coast Air Basin and their impact on ammonium nitrate formation, Geophy. Res. Lett., 39, L07804, doi:10.1029/2012GL051197, 2012.

Oliveras, I., Anderson, L. O., and Malhi, Y.: Application of remote sensing to understanding fire regimes and biomass burning emissions of the tropical Andes, Global Biogeochem. Cy., 28, 480496, 2014.
Pan, L., Gille, J. C., Edwards, D. P., Bailey, P. L., and Rodgers, C. D.: Retrieval of tropospheric carbon monoxide for the mopitt experiment, J. Geophys. Res., 103, 32277-32290, 1998.

Park, R. J., Jacob, D., Field, B. D., Yantosca, R. M., and Chin, M.: Natural and transboundary pollution influences on sulfate-nitrate-ammonium aerosols in the United States: implications for policy, J. Geophys. Res., 109, D15204, doi:10.1029/2003JD004473, 2004.

Paulot, F. and Jacob, D. J.: Hidden Cost of U.S. Agricultural Exports: Particulate Matter from Ammonia Emissions, Environ. Sci. Technol., 48, 903-908, 2014.

Paulot, F., Jacob, D. J., and Henze, D. K.: Sources and processes contributing to nitrogen deposition: An adjoint model analysis applied to biodiversity hotspots worldwide, Environ. Sci. Technol., 47, 3226-3233, 2013.

Paulot, F., Jacob, D. J. Pinder, R. W., Bash, J. O., Travis, K., and Henze, D. K.: Ammonia emissions in the United States, European Union, and China derived by high-resolution inversion of ammonium wet deposition data: Interpretation with a new agricultural emissions inventory (MASAGE_NH3), J. Geophys. Res.-Atmos., 119, 4343-4364, doi:10.1002/2013JD021130, 2014.

Pinder, R. W., Walker, J. T., Bash, J. O., Cady-Pereira, K. E., Henze, D. K., Luo, M., Osterman, G. B., and Shephard, M. W.: Quantifying spatial and seasonal variability in atmospheric ammonia with in situ and space-based observations, Geophys. Res. Lett., 38, L04802, doi:10.1029/2010GL046146, 2011.

Pope, C. A., Burnett, R. T., Thun, M. J., Calle, E. E., Krewski, D., Ito, K., and Thurston, G. D.: Lung Cancer, Cardiopulmonary, Mortality, and Long-term Exposure to Fine Particulate Air Pollution, J. Am. Med. Assoc., 287, 1132-1141, 2002.

R'Honi, Y., Clarisse, L., Clerbaux, C., Hurtmans, D., Duflot, V., Turquety, S., Ngadi, Y., and Coheur, P.-F.: Exceptional emissions of $\mathrm{NH}_{3}$ and $\mathrm{HCOOH}$ in the 2010 Russian wildfires, Atmos. Chem. Phys., 13, 4171-4181, doi:10.5194/acp-13-41712013, 2013.

Rienecker, M. M., Suarez, M. J., Gelaro, R., Todling, R., Bacmeister, J., Liu, E., Bosilovich, M. G., Schubert, S. D., Takacs, L., Kim, G.-K., Bloom, S., Chen, J., Collins, D., Conaty, A., da Silva, A., Gu, W., Joiner, J., Koster, R. D., Lucchesi, R., Molod, A., Owens, T., Pawson, S., Pegion, P., Redder, C. R., Reichle, R., Robertson, F. R., Ruddick, A. G., Sienkiewicz, M., and Woollen, J.: MERRA: NASA's Modern-Era Retrospective Analysis for Research and Applications, J. Climate, 24, 3624-3648, doi:10.1175/JCLI-D-11-00015.1, 2011.

Rodgers, C. D.: Inverse Methods for Atmospheric Sounding, Theory and Practice, World Sci., River Edge, N.J., 2000.

Rodgers, C. D. and Connor, B. J.: Intercomparison of remote sounding instruments, J. Geophys. Res., 108, 4116, doi:10.1029/2002JD002299, 2003.

Roelle, P. A. and Aneja, V. P.: Environmental Simulation Chambers: Application to Atmospheric Chemical Processes, Springer, 13 January 2006, Science, 457 pp., 2002.

Shephard, M. W., Cady-Pereira, K. E., Luo, M., Henze, D. K., Pinder, R. W., Walker, J. T., Rinsland, C. P., Bash, J. O., Zhu, L., Payne, V. H., and Clarisse, L.: TES ammonia retrieval strategy and global observations of the spatial and seasonal variability of ammonia, Atmos. Chem. Phys., 11, 10743-10763, doi:10.5194/acp-11-10743-2011, 2011. 
Sommer, S. G., Schjoerring, J. K., and Denmead, O. T.: Ammonia Emission from Mineral Fertilizers and Fertilized Crops, Adv. Agron., 82, 557-622, 2004.

Strow, L., Hannon, S., Machado, S., Motteler, H., and Tobin, D.: An Overview of the AIRS Radiative Transfer Model, IEEE T. Geosci. Remote Sens., 41, 303-313, 2003.

Susskind, J., Barnet, C. D., and Blaisdell, J. M.: Retrieval of atmospheric and surface parameters from AIRS/AMSU/HSB data in the presence of clouds, IEEE T. Geosci. Remote Sens., 41, 390409, 2003.

Sutton, M., Erisman, J., Dentener, F., and Moller, D.: Ammonia in the environment: From ancient times to the present, Environ. Pollut., 156, 583-604, doi:10.1016/j.envpol.2008.03.013, 2008.

Sutton, M. A., Nemitz, E., Erisman, J. W., Beier, C., Bahl, K. B., Cellier, P., de Vries, W., Cotrufo, F., Skiba, U., Di Marco, C., Jones, S., Laville, P., Soussana, J. F., Loubet, B., Twigg, M., Famulari, D., Whitehead, J., Gallagher, M. W., Neftel, A., Flechard, C. R., Herrmann, B., Calanca, P. L., Schjo- erring, J. K., Daemmgen, U., Horvath, L., Tang, Y. S., Emmett, B. A., Tietema, A., Penuelas, J., Kesik, M., Brueggemann, N., Pilegaard, K., Vesala, T., Campbell, C. L., Olesen, J. E., Dragosits, U., Theobald, M. R., Levy, P., Mobbs, D. C., Milne, R., Viovy, N., Vuichard, N., Smith, J. U., Smith, P., Bergamaschi, P., Fowler, D., and Reis, S.: Challenges in quantifying biosphere-atmosphere exchange of nitrogen species, Environ. Pollut., 150, 125-139, doi:10.1016/j.envpol.2007.04.014, 2007.

Updyke, K. M., Nguyen, T. B., and Nizkorodov, S. A.: Formation of brown carbon via reactions of ammonia with secondary organic aerosols from biogenic and anthropogenic precursors, Atmos. Environ., 63, 22-31, 2012.

Van Damme, M., Wichink Kruit R.J., Schaap M., Clarisse L., Clerbaux C., Coheur P.-F., Dammers E., Dolman A.J., Erisman J.W., Evaluating 4 years of atmospheric ammonia (NH3) over Europe using IASI satellite observations and LOTOS-EUROS model results, J. Geophys. Res.-Atmos., 119, 9549-9566, 2014.

Van Damme, M., Clarisse, L., Dammers, E., Liu, X., Nowak, J. B., Clerbaux, C., Flechard, C. R., Galy-Lacaux, C., Xu, W., Neuman, J. A., Tang, Y. S., Sutton, M. A., Erisman, J. W., and Coheur, P. F.: Towards validation of ammonia $\left(\mathrm{NH}_{3}\right)$ measurements from the IASI satellite, Atmos. Meas. Tech., 8, 15751591, doi:10.5194/amt-8-1575-2015, 2015.

Walker, J. M., Philip, S., Martin, R. V., and Seinfeld, J. H.: Simulation of nitrate, sulfate, and ammonium aerosols over the United States, Atmos. Chem. Phys., 12, 11213-11227, doi:10.5194/acp12-11213-2012, 2012.
Wang, J., Jacob, D. J., and Martin, S. T.: Sensitivity of sulfate direct climate forcing to the hysteresis of particle phase transitions, J. Geophys. Res., 113, D11207, doi:10.1029/2007JD009368, 2008.

Warner, J., Carminati, F., Wei, Z., Lahoz, W., and Attié, J.-L.: Tropospheric carbon monoxide variability from AIRS under clear and cloudy conditions, Atmos. Chem. Phys., 13, 12469-12479, doi:10.5194/acp-13-12469-2013, 2013.

Warner, J. X., Comer, M. M., Barnet, C. D., McMillan, W. W., Wolf, W., Maddy, E., and Sachse, G.: A Comparison of Satellite Tropospheric Carbon Monoxide Measurements from AIRS and MOPITT During INTEX-A, J. Geophys. Res., 112, D12S17, doi:10.1029/2006JD007925, 2006.

Warner, J. X., Wei, Z., Strow, L. L., Barnet, C. D., Sparling, L. C., Diskin, G., and Sachse, G.: Improved agreement of AIRS tropospheric carbon monoxide products with other EOS sensors using optimal estimation retrievals, Atmos. Chem. Phys., 10, 95219533, doi:10.5194/acp-10-9521-2010, 2010.

Whitburn, S., Van Damme, M., Kaiser, J. W., van der Werf, G. R., Turquety, S., Hurtmans, D., Clarisse, L., Clerbaux, C., and Coheur, P.-F.: Ammonia emissions in tropical biomass burning regions: Comparison between satellite-derived emissions and bottom-up fire inventories, Atmos. Environ., 121, 42-54, doi:10.1016/j.atmosenv.2015.03.015, 2015.

Wu, S.-Y., Krishnanb, S., Zhang, Y., and Aneja, V.: Modeling atmospheric transport and fate of ammonia in North Carolina - Part I: Evaluation of meteorological and chemical predictions, Atmos. Environ., 42, 3419-3436, 2007.

Yamaji, K., Ohara, T., and Akimoto, H.: Regional-specific emission inventory for $\mathrm{NH}_{3}, \mathrm{~N}_{2} \mathrm{O}$, and $\mathrm{CH}_{4}$ via animal farming in south, southeast, and East Asia, Atmos. Environ., 38, 7111-7121, 2004

Yevich, R. and Logan, J. A.: An assessment of biofuel use and burning of agricultural waste in the developing world, Global Biogeochem. Cy., 17, 1095, doi:10.1029/2002GB001952, 2003.

Zhu, L., Henze, D. K., Cady-Pereira, K. E., Shephard, M. W., Luo, M., Pinder, R. W., Bash, J. O., and Jeong, G.-R.: Constraining U.S. ammonia emissions using TES remote sensing observations and the GEOS-Chem adjoint model, J. Geophys. Res.-Atmos., 118, 3355-3368, doi:10.1002/jgrd.50166, 2013. 